\title{
SEASONAL VARIATION OF VOLATILE POLY AROMATIC HYDROCARBONS (PAHS) RELEASED FROM DIFFERENT SOURCES IN SOUTH CAIRO
}

\author{
Howaihy, M. A. ${ }^{(1)}$; Zahran, A. A. $^{(2)}$; Ragab, M. H. ${ }^{(1)}$ \\ and Nour Eldeen, M. M. \\ 1) Institute of Environmental Studies and Research, Ain Shams University \\ 2) Environmental Studies and Research Institute, University of Sadat City
}

\begin{abstract}
Understanding the seasonal variations of polycyclic aromatic hydrocarbons (PAHs) concentrations in ambient air in urban/rural or industrial regions is important to the effective control of air pollution in these regions. Based on an approximately a year round dataset (from January to November 2014), a total of 48 atmospheric samples were collected by high volume active air sampler over one year seasonal monitoring in order to assess the variation of PAHs concentrations in different areas through different seasons in south Al Tabbin area. The gaseous and particulate phases of PAHs were extracted and analyzed using GC/MS together. The total air concentrations of 16 USEPA PAHs in the study area ranged from $76.48 \pm$ $19.44 \mu \mathrm{g} / \mathrm{m}^{3}$ to $26995.86 \pm 2835.91 \mu \mathrm{g} / \mathrm{m}^{3}$, with an average concentration of $7085.08 \pm 773.98 \mu \mathrm{g} / \mathrm{m}^{3}$. Seasonal trends of PAH concentrations were observed with high concentration in winter and low in summer where the average concentration of PAHs in winter were $\sim 1.6$ times higher than that in summer. This mainly attributed to meteorological conditions.
\end{abstract}

Key words: Poly Aromatic Hydrocarbons; Seasonal variation; South Tabbin 
J. Environ. Sci.

Institute of Environmental Studies and Research - Ain Shams University

\section{INTRODUCTION}

Polycyclic aromatic hydrocarbons (PAHs) are a large group of ubiquitous persistent semi-volatile organic compounds (SVOCs). They are comprised of two or more fused benzene rings arranged in various configurations. They are a group of carcinogenic and mutagenic pollutants that are resistant to degradation and can remain in the environment for long periods due to their high degree of conjugation and aromaticity. They have a relatively low solubility in water, but are highly lipophilic. Most of the PAHs with low vapor pressure in the air are adsorbed on particles. When dissolved in water or adsorbed on airborne particulate matter, PAHs can undergo photodecomposition when exposed to ultraviolet light from solar radiation. In the atmosphere, PAHs can react with pollutants such as ozone, nitrogen oxides and sulfur dioxide, yielding diones, nitro- and dinitro-PAHs, and sulfonic acids, respectively.

There is much information on the multi-ringed heavier PAHs but have left the lighter vapor-phase PAH components rather neglected. Although these lighter compounds have weaker carcinogenic/mutagenic properties, they are the most abundant in the urban atmosphere and react with other pollutants to form more toxic derivatives (Park et al., 2002). A PAH classification is done based on their number of aromatic rings, which is used to construct the distribution pattern of the PAHs for each fraction. PAHs can be classified by their numbers of aromatic ring as follows: 2-ring including Nap; 3-ring including ACE, ACY, FLO, PHE and ANT; 4-ring including FLA, PYR, BaA and CHR; 5-ring including $\mathrm{BbF}, \mathrm{BkF}$ and $\mathrm{BaP}$; 6-ring 
including DBahA, IcdP and BghiP. They can also be further classified into lower molecular weight (LMW) containing 2 and 3-ring PAHs, middle molecular weight (MMW) containing 4-ring PAHs and higher molecular weight PAHs (HMW) containing 5 and 6-ring PAHs (Yang et al., 1998, 2002; Chen et al., 2003and 2007).

However, in Egypt, Al Tabbin city that is located in south of Cairo governorate and track neighborhood of Helwan city. Its land area is $25 \mathrm{~km} 2$. The population in the residential area is about 100,000 according to the population count in 2014. This city is considered as one of the largest industrial cities in Egypt where it has the largest factories for the heavy industries such as "Egyptian Iron and Steel company", "National Cement company", "Helwan Cement company", "Nasr Company for Coke and Basic Chemicals", "Egyptian company for Metallurgical Industries" and "Helwan Fertilizers Company" as well as many bricks plants. Furthermore, it is bordered by two heavy trafficked highways, Nile Cornish and Al Tabbin Autostrad road.

The main objectives of this study is to measure the concentration levels of ambient PAHs, study the spatial and temporal variations of ambient PAH levels and their possible relationships with meteorological parameters inordert to identify and allocate possible sources of PAHs using diagnostic ratio. 
J. Environ. Sci.

Institute of Environmental Studies and Research - Ain Shams University

\section{METHODOLOGY AND TECHNIQUES}

The applied methodology in this study is based on US-EPA Method TO-13A (Compendium Method for determination of PAHs in ambient air). Concisely, the method is based on using a High-Volume Air Sampler for collection of PAHs from ambient air onto the sampling module that consists of particle filter and high volume collection tube containing adsorbent media (i.e. sorbent cartridge).

The study area for this study is located in the south of El Tabbin city with geographical coordinates of $29^{\circ} 44^{\prime} 59.92^{\prime \prime} \mathrm{N}$ to $29^{\circ} 47^{\prime} 35.12^{\prime \prime} \mathrm{N}$ latitude and $31^{\circ} 17^{\prime} 35.45^{\prime \prime} \mathrm{E}$ to $31^{\circ} 20^{\prime} 12.13^{\prime \prime} \mathrm{E}$ longitude, and total area of $25 \mathrm{~km}^{2}$. The selected sampling area is surrounded by a mixture of urban, industrial, commercial and traffic activities as they are possible sources of PAHs specially the coke production plant. Furthermore, this area represents a large urban industrialized area in El Tabbin city and even in Helwan city where metallurgical, chemical, coal, petrochemical, bricks and cement-producing plants are located. The sampling was conducted in four location within the study area they are namely Tabbin Institute (TIMS), Residential Area (RA), Coke Factory (CK) and Arab Abu Said (AAS).

The applied method in this study utilized the High-Volume Air Sampler (Andersen Instruments Inc., 500 Technology Ct., Smyrna, GA) system to acquire sufficient sample for analysis. This system is capable of collecting ambient air through the filter/sorbent cartridge at a flow rate of approximately $225 \mathrm{~L} / \mathrm{min}$ (i.e. $0.225 \mathrm{~m}^{3} / \mathrm{min}$ ) to obtain a total sample volume of greater than $300 \mathrm{~m}^{3}$ over a 24-hour period. Moreover, this method provides efficient 
collection of most PAHs involving two member rings or higher either in a particulate phase or in a gaseous phase through utilization of quartz fiber filter with adsorbent cartridge consists of Poly urethane foam (PUF) and XAD-2 polymer resin as a sorbent media where XAD-2® is intermediated between two layers of polyurethane foam (PUF) in sandwiching configuration in order to minimize breakthrough of highly volatile PAHs. The sampling module inside the high-volume sampler is consists of metal filter holder capable of holding a 102-mm circular particle filter supported by a 16-mesh stainless-steel screen and attaching to a metal cylinder capable of holding a 65-mm outer diameter (O.D.) \& 60-mm inner diameter (I.D.) x 125-mm in height borosilicate glass sorbent cartridge containing the adsorbent media (PUF and XAD-2®).

The GC-MS instrument is combined of two parts: The gas chromatograph (GC) and the mass spectrometer (MS), for general specifications for Shimadzu - GCMS-QP5050A, it is a benchtop quadrupole mass spectrometer features an extended mass range to 900 Daltons and optional positive and negative chemical ionization (PCI and NCI). The efficient $150 \mathrm{~L} / \mathrm{sec}$ turbomolecular pump and rotary pump quickly achieve a high vacuum in less than 5 minutes and this will reflect in minimal downtime. For developing calibration curve for GC/MS analysis, the stock standard solution of 16 PAHs mixed in methylene chloride: methanol (50:50) at the concentration of $2000 \mu \mathrm{g} / \mathrm{ml}$ (Sigma Aldrich Chemical Co. Inc. USA) was diluted first to concentration of $25 \mathrm{ng} / \mu \mathrm{L}$ by taking $125 \mu \mathrm{L}$ of the stock PAH standard and diluting with hexane in a $10-\mathrm{mL}$ volumetric flask. After that, five concentration levels of PAH standards (i.e., $2.50 \mathrm{ng} / \mu \mathrm{L}, 1.25 \mathrm{ng} / \mu \mathrm{L}, 0.50$ 
$\mathrm{ng} / \mu \mathrm{L}, 0.25 \mathrm{ng} / \mu \mathrm{L}$, and $0.10 \mathrm{ng} / \mu \mathrm{L}$ ) were prepared prior GC/MS analysis, each $1 \mathrm{~mL}$ aliquot of the five calibration standards as well as $1 \mathrm{~mL}$ portion of the sample extracts are spiked with $10 \mu \mathrm{L}$ at concentration of $50 \mathrm{ng} / \mu \mathrm{L}$ (after 1:40 dilution) of the mixture of deuterated PAH internal standard (Isotopically labeled PAH isomers at the concentration of $2000 \mu \mathrm{g} / \mathrm{mL}$ mixed in methylene chloride, Sigma Aldrich Chemical Co. Inc. USA), to yield a final concentration of $0.5 \mathrm{ng}$. This internal standard was used to quantify and correct the amounts of specific PAHs found in the samples.

\section{RESULTS AND DISCUSSION}

The atmospheric PAHs mass concentrations for different sampling sites and seasons under study are provided in Tables 1.A-D. As can be seen, the total amounts of analyzed PAHs (i.e. Total $\sum 16$ PAHs) in the area under study varied from $76.48 \pm 19.44 \mu \mathrm{g} / \mathrm{m}^{3}$ in RA site to $26995.86 \pm 2835.91$ $\mu \mathrm{g} / \mathrm{m}^{3}$ in the CK site with a mean concentration of $7085.08 \pm 773.98 \mu \mathrm{g} / \mathrm{m}^{3}$. As illustrated in Table 1 A-D, the PAH concentration levels demonstrate that the area under study is influenced by regional sources. In the nutshell, the total $\sum 16$ PAHs concentrations as well as the average concentrations of $\sum 16$ PAHs over the seasonal sampling period in the different functional zones of the study area can be ordered as follow: CK site (at the border of Coke production plant) $\left(26995.86 \pm 2835.91 \mu \mathrm{g} / \mathrm{m}^{3}\right.$ with the average concentration of $6749 \pm 709 \mu \mathrm{g} / \mathrm{m}^{3}$ ) > TIMS site (at the prevailing wind directions carried the combustion emissions coming from stationary sources of several industrial complexes) $\left(901.34 \pm 166.22 \mu \mathrm{g} / \mathrm{m}^{3}\right.$ with the average concentration 
of $225 \pm 42 \mu \mathrm{g} / \mathrm{m}^{3}$ ) $>$ AAS site (at $\leq 1 \mathrm{Km}$ northwest of the stationary exhausts of the bricks plants) (366.64 $\pm 74.35 \mu \mathrm{g} / \mathrm{m} 3$ with the average concentration of $92 \pm 17 \mu \mathrm{g} / \mathrm{m}^{3}$ ) > RA site (dual impacts from the vicinity to industrial complexes and vehicle emissions) $(76.48 \pm 19.44 \mu \mathrm{g} / \mathrm{m} 3$ with the average concentration of $19 \pm 4 \mu \mathrm{g} / \mathrm{m}^{3}$ ).

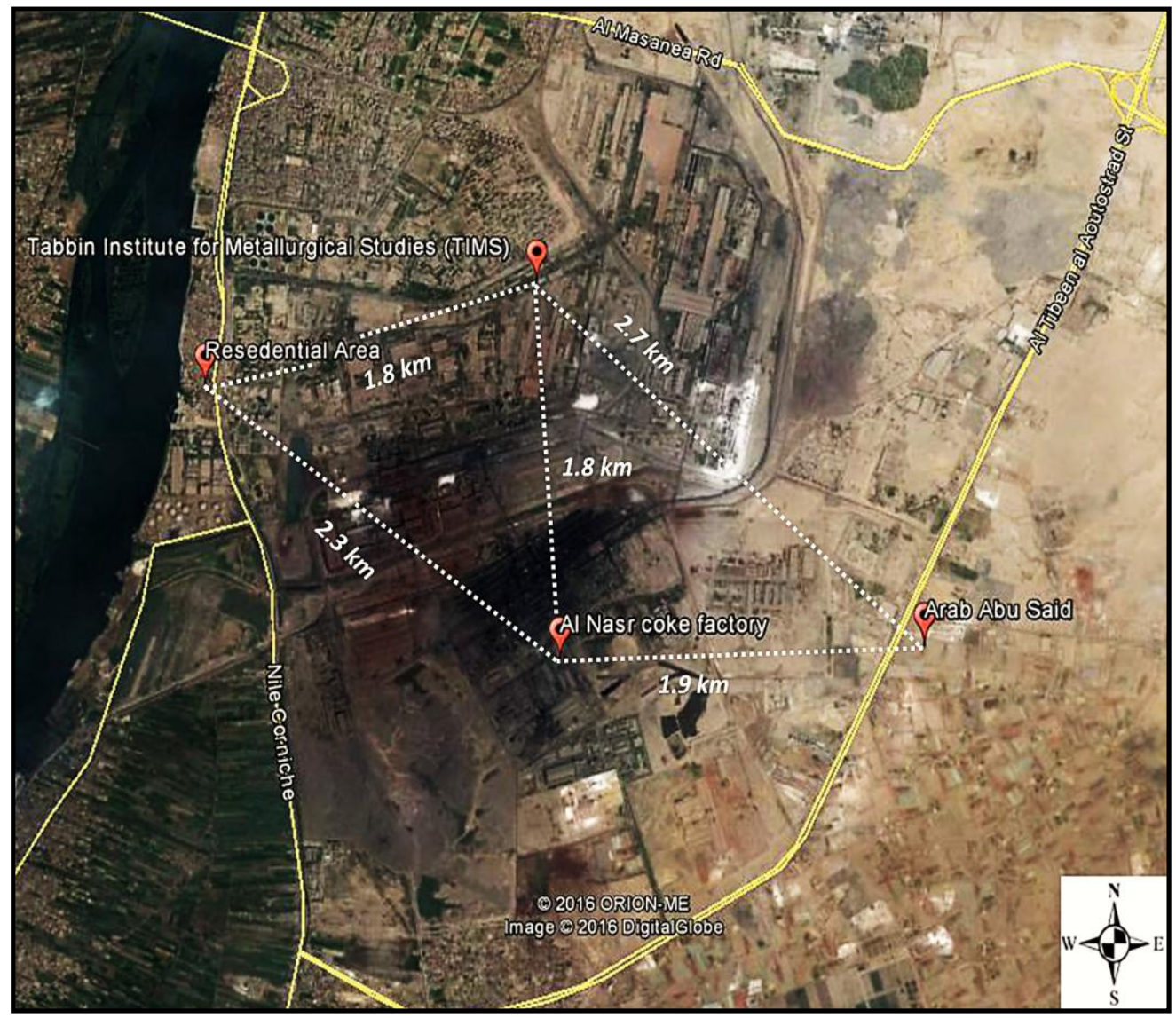

Figure 1: Map of the study area where the red spots indicate sampling sites and the yellow lines indicate national ways. 
In comparison with others, Wu et al. (2014) pointed out that the total PAHs concentrations associated with $\mathrm{PM}_{2.5}$ and $\mathrm{PM}_{10}$ in the E'erduosi city in china decreasing as coal-chemical base site > heavy industrial site > residential site with heavy traffic > suburban site surrounded by grassland > background site where PAHs concentrations in the coal-chemical base site are 250 and 31 times of those in the background site for $\mathrm{PM}_{2.5}$ and $\mathrm{PM}_{10}$ and respectively.

For the sake of illustration, figure 2 shows the measured total $\mathrm{PAH}$ concentrations (i.e. Total $\sum 16$ PAHs) over the seasonal sampling period for the different sampling sites, while figure 4.2 shows the measured total PAHs concentrations for each individual compound ( $\sum \mathrm{i}$ PAHs) over the seasonal sampling period for each sampling site. Obviously from both figures, the highest mass concentrations of PAHs among the four sampling sites (either for Total $\sum 16$ PAHs or $\sum$ i PAHs) are found in the Coke samples whereas the lowest values are found in the Residential Area samples.

Kim et al. (2013) also indicated that the highest values for atmospheric PAHs are generally found when industrial, rather than traffic or residential, contributions are dominant. On the other hand, Zhang and Tao (2009) concluded that biofuel; wildfire, domestic coal combustion, coke production and open straw burning are the most important sources for global atmospheric PAHs, accounting for $56.7 \%, 12.4 \%, 11.7 \%, 7.0 \%$ and $2.7 \%$, respectively. However, the combustion derived PAHs (COMPAHs), including FLA, PYR, CHR, BbF, BkF, BaA, BaP, IcdP, BghiP (Bourotte et al., 2005; Kong et al., 2010) can be used to identify the influence of combustion sources on PAHs. 
The total concentrations of COMPAHs in this study for the different sampling sites are ranged from $63.24 \pm 17.35 \mu \mathrm{g} / \mathrm{m}^{3}$ to $17546.97 \pm 1848.55 \mu \mathrm{g} / \mathrm{m}^{3}$ accounting for $65 \%-83 \%$ of total PAHs with the highest mass percentages occurred in RA. The calculated $\mathrm{COMPAH} / \Sigma \mathrm{PAH}$ ratios for different sampling sites are $0.65,0.61,0.75$ and 0.83 for CK, TIMS, AAS and RA, respectively.

$\mathrm{Wu}$ et al. (2014) demonstrated that the total concentrations of COMPAHs cover $42 \%-84 \%$ and $75 \%-82 \%$ of PAHs associated with $\mathrm{PM}_{2.5}$ and $\mathrm{PM}_{10}$, with the highest mass percentages found in Dongsheng (DS) site of sampling area of E'erduosi city in china. This site represent a residential site at the central urban adjacent to a heavy-traffic road.

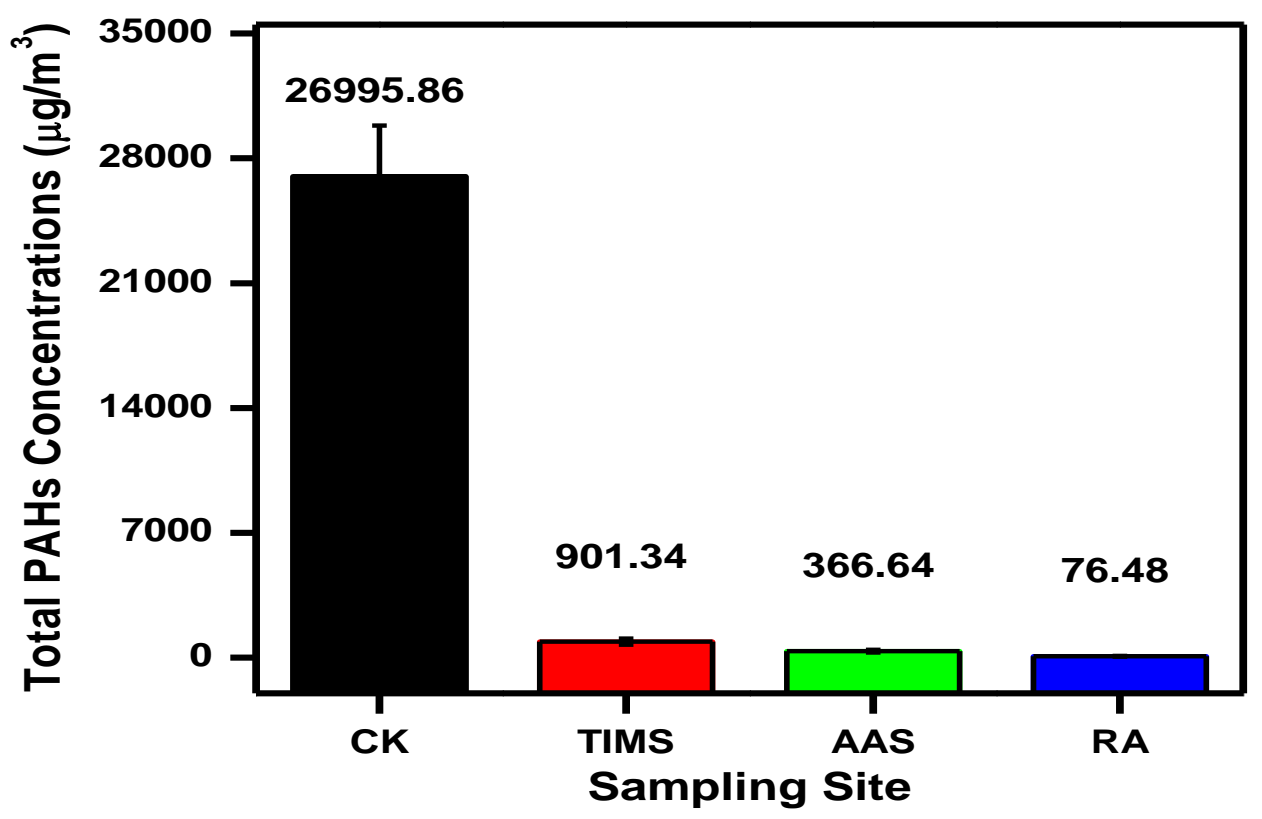

Figure 2: Total PAHs Concentrations over the seasonal sampling period for all sampling sites. 
J. Environ. Sci.

Institute of Environmental Studies and Research - Ain Shams University
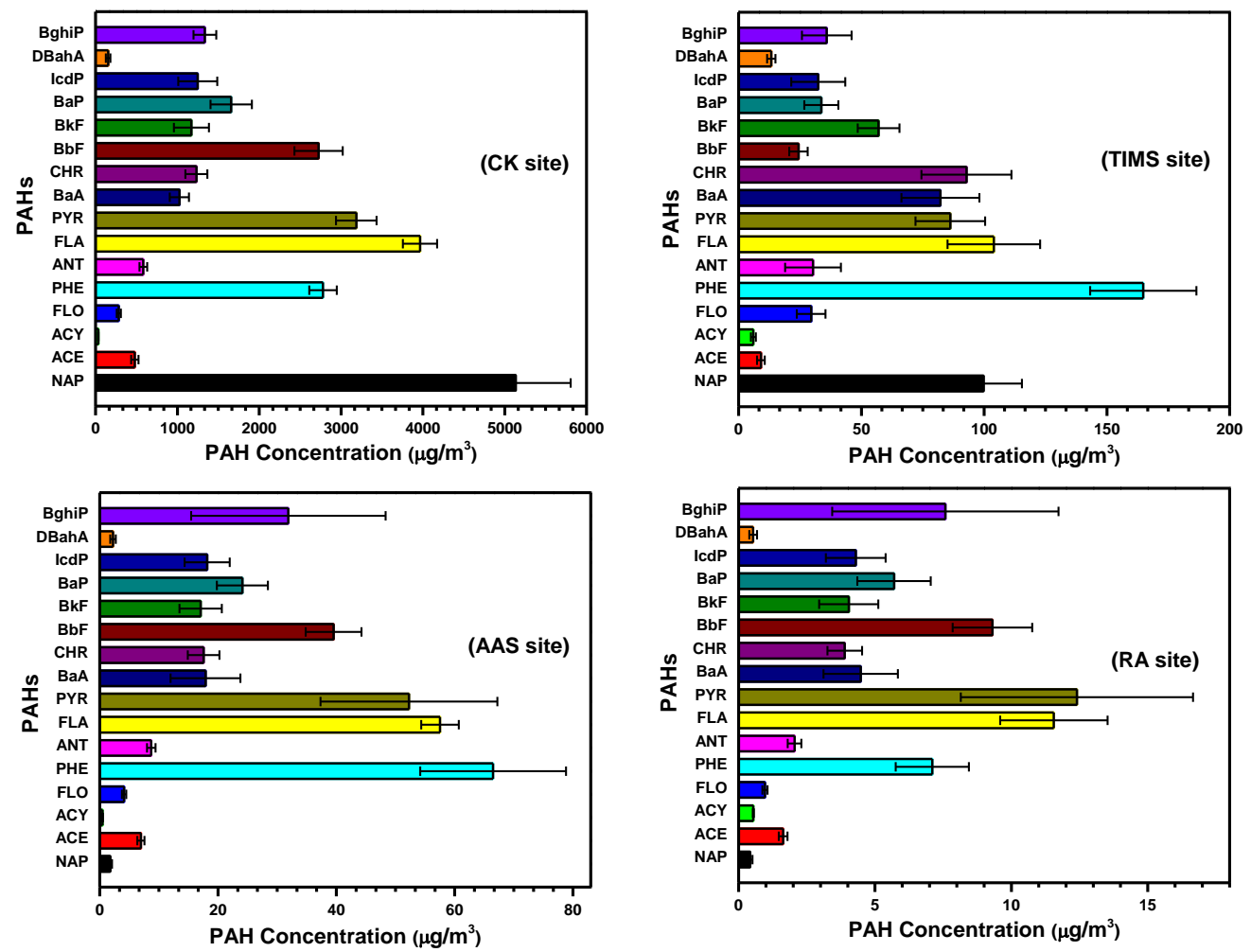

Figure 3: Total of the individual PAH concentrations over the seasonal period for each sampling site.

As an indicator PAHs, BaP was the most carcinogenic PAHs (Johansson and Bavel, 2003). Its content in this study over the seasonal sampling period varied from $5.7 \pm 1.4 \mu \mathrm{g} / \mathrm{m}^{3}$ in RA samples to $1657 \pm 252 \mu \mathrm{g} / \mathrm{m} 3$ in $\mathrm{CK}$ samples, hold a mean value of $430 \pm 66 \mu \mathrm{g} / \mathrm{m}^{3}$, accounting for $\sim 4 \%$ in TIMS to $\sim 8 \%$ in RA of total PAHs concentrations in study area. However, the total mass concentrations of the carcinogenic PAHs ( $\sum \mathrm{C}-\mathrm{PAHs}$ ) (including BaA, CHR, BbF, BkF, BaP, IcdP, DBahA) (USEPA, 1999 \& 2008) over the 
seasonal sampling period in this study are in the range of $32 \pm 7 \mu \mathrm{g} / \mathrm{m}^{3}$ in RA samples to $9213 \pm 1279 \mu \mathrm{g} / \mathrm{m}^{3}$ in $\mathrm{CK}$ samples with the average concentrations of $2429 \pm 344 \mu \mathrm{g} / \mathrm{m}^{3}$, accounting for $34-42 \%$ of total PAHs.

As illustrated in Table 1.A-D, since LMW and MMW -PAHS represents the gas phase and HMW -PAHS represent the solid phase the mass concentrations of law macular weight (LMW), medium molecular weight (MMW) and high molecular weight (HMW) -PAHs are in the range of $9294.54 \pm 959.45-12.71 \pm 1.95 \mu \mathrm{g} / \mathrm{m}^{3}, 9409.73 \pm 708.90-32.33 \pm 8.22$ $\mu \mathrm{g} / \mathrm{m}^{3}, 8291.59 \pm 1167.57-31.44 \pm 9.27 \mu \mathrm{g} / \mathrm{m}^{3}$, respectively. Relatively high proportions of MMW-PAHs ( 35\% - 43\%) and HMW-PAHs $(\sim 31 \%-\sim$ $41 \%$ ) were detected in samples from different sampling sites. Particularly, for CK and TIMS sites, LMW-, MMW-, and HMW-PAHs represent 34\%, $38 \%, \sim 35 \%$ and $\sim 41 \%, \sim 31 \%, \sim 22 \%$, respectively, of the total PAHs, whereas for AAS and RA sites, the MMW-PAHs were predominantly compounds of the total PAHs (i.e. $\sim 40 \%$ and $\sim 43 \%$, respectively) followed by HMW-PAHs accounting for $\sim 36 \%$ and $\sim 41 \%$ then LMW-PAHs (i.e. $24 \%$ and $\sim 17 \%$ ), respectively.

Figure 3 shows the ring distribution of the PAHs over the sampling period for each sampling site. In general, for the area under study, 4-ring PAHs were the dominant form of PAHs measured in samples with the values ranged from $35 \%$ to $43 \%$. Then 3-ring and 5-ring PAHs were varying from $15 \%-27 \%$ and $13 \%-25 \%$, respectively. For 2-ring PAHs, the mean percentage for different sampling sites was $8 \%$. 
However, results for the ring distribution of PAHs are comparable to others where 2- and 3-ring PAHs are the dominant form of the PAHs measured in coke manufacturing (Khalili et al., 1995; Yang et al., 1998). You (2008) concluded that 4-ring PAHs were most abundant during coal combustion, accounting for about $80 \%, 70 \%$ and $90 \%$ at three individual sampling points. Same conclusion was made by Arditsoglou et al., (2004) that the PAHs were dominated by 4-ring species (48-62\%) followed by 3-ring compounds (38-41\%) in fly ashes samples from lignite-fired power plants. 5ring PAHs exhibited equal or even higher contribution respect to 3- and 4ring species in coke oven stacks (Manoli et al., 2004). Additionally, Ravindra et al., (2006) indicated that the major source for 3- and 4-ring PAHs is coal combustion, while the major source for HMW PAHs (BaP, BbF, BghiP and Ind) is gasoline vehicles. Therefore, PAHs at the four sites may come mainly from atmospheric transport of the coal combustion and vehicle emissions as both dominated the PAH sources. Regardless, as shown in figure 4, the total PAHs concentrations (i.e. Total $\sum 16$ PAHs) over the seasonal sampling period for the different sampling sites are well correlated with $\sum$ LMW-PAHs, ¿MMW-PAHs, $\sum$ HMW-PAHs, $\sum$ COMPAHs, $\sum$ C-PAHs over the seasonal sampling period for the different sampling sites with the correlation coefficients higher to 0.99 . 


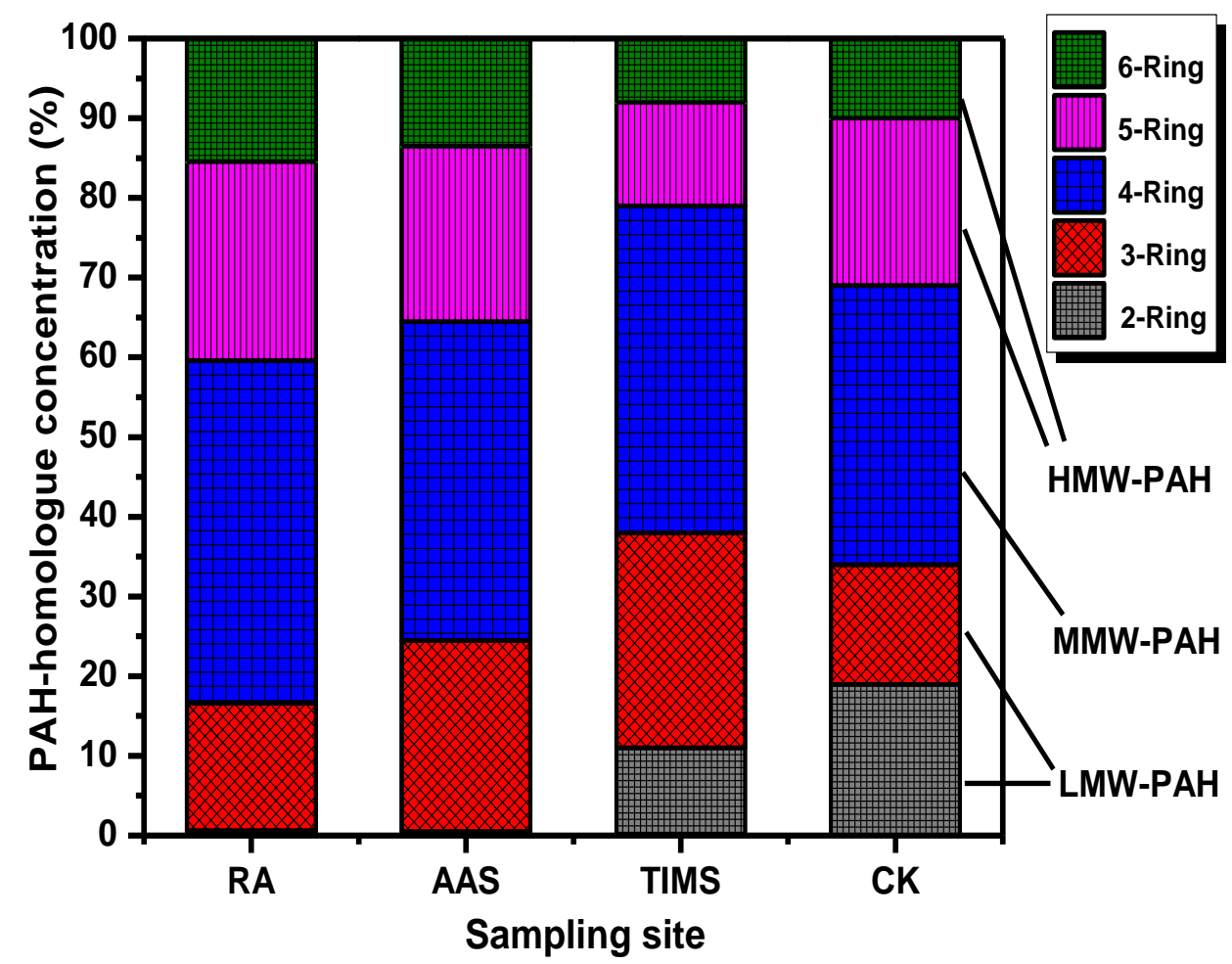

Figure 4. PAH-Homologue concentrations of samples from different sites 
J. Environ. Sci.

Institute of Environmental Studies and Research - Ain Shams University

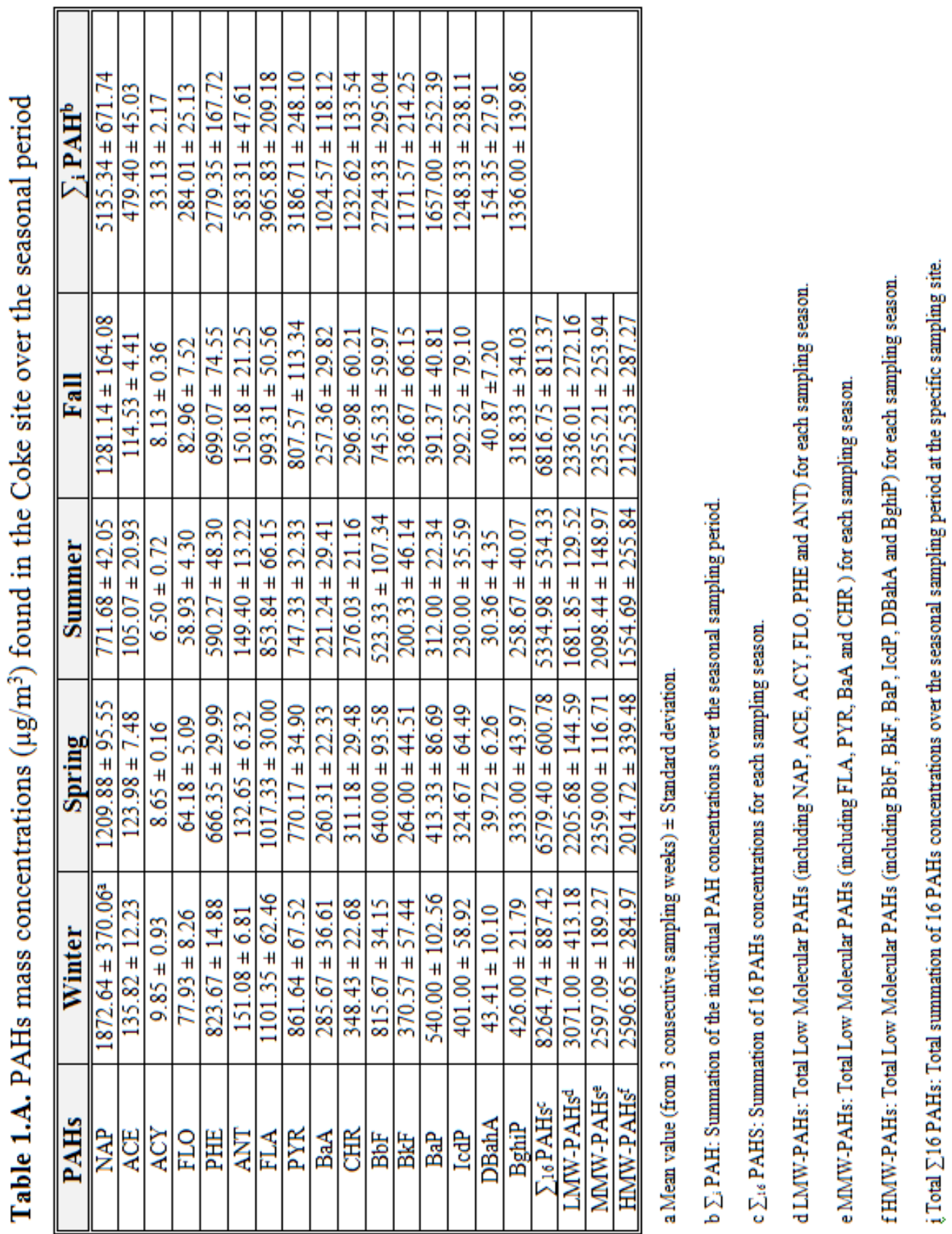




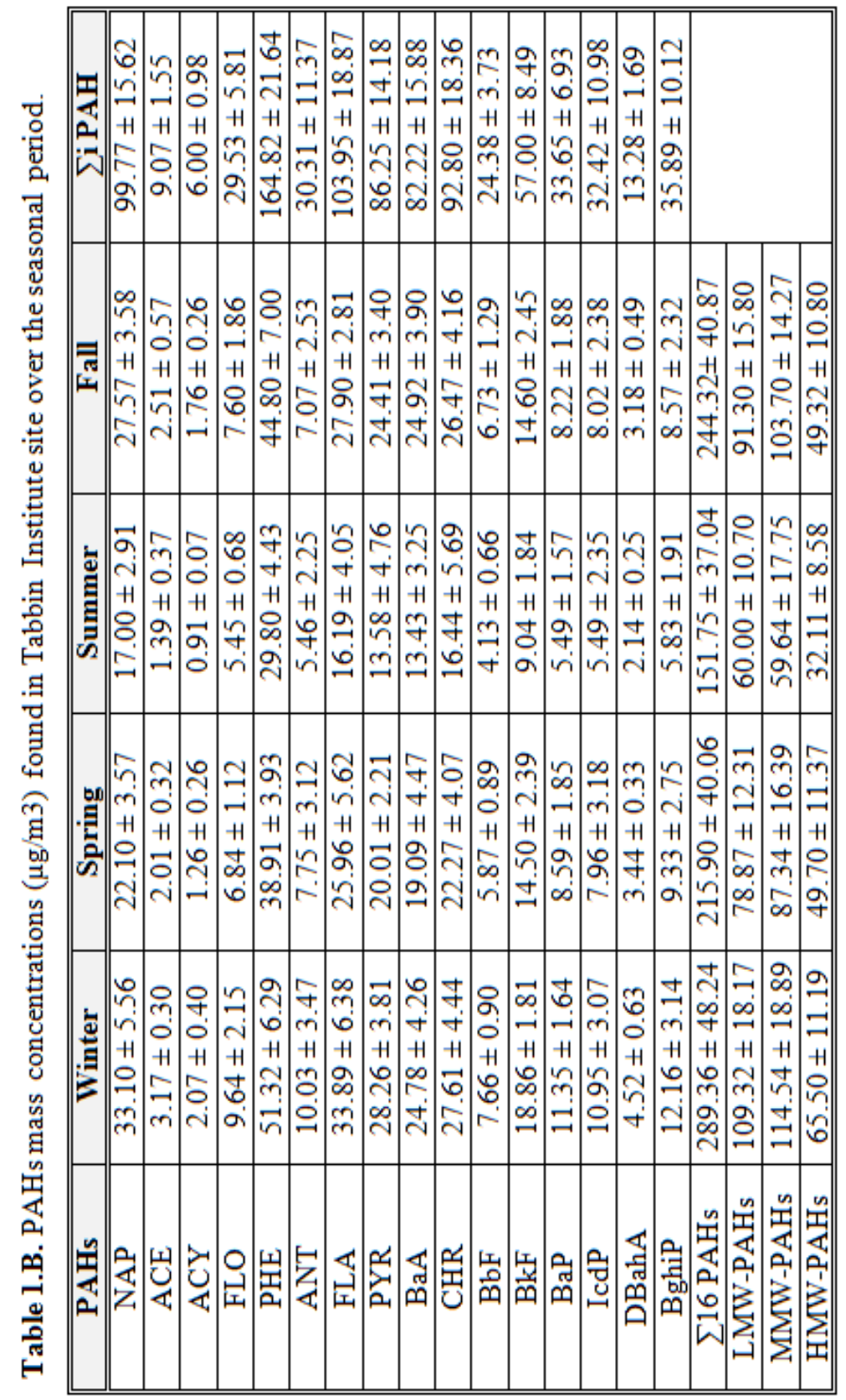

Vol. 36, No.3, Dec. 2016 
J. Environ. Sci.

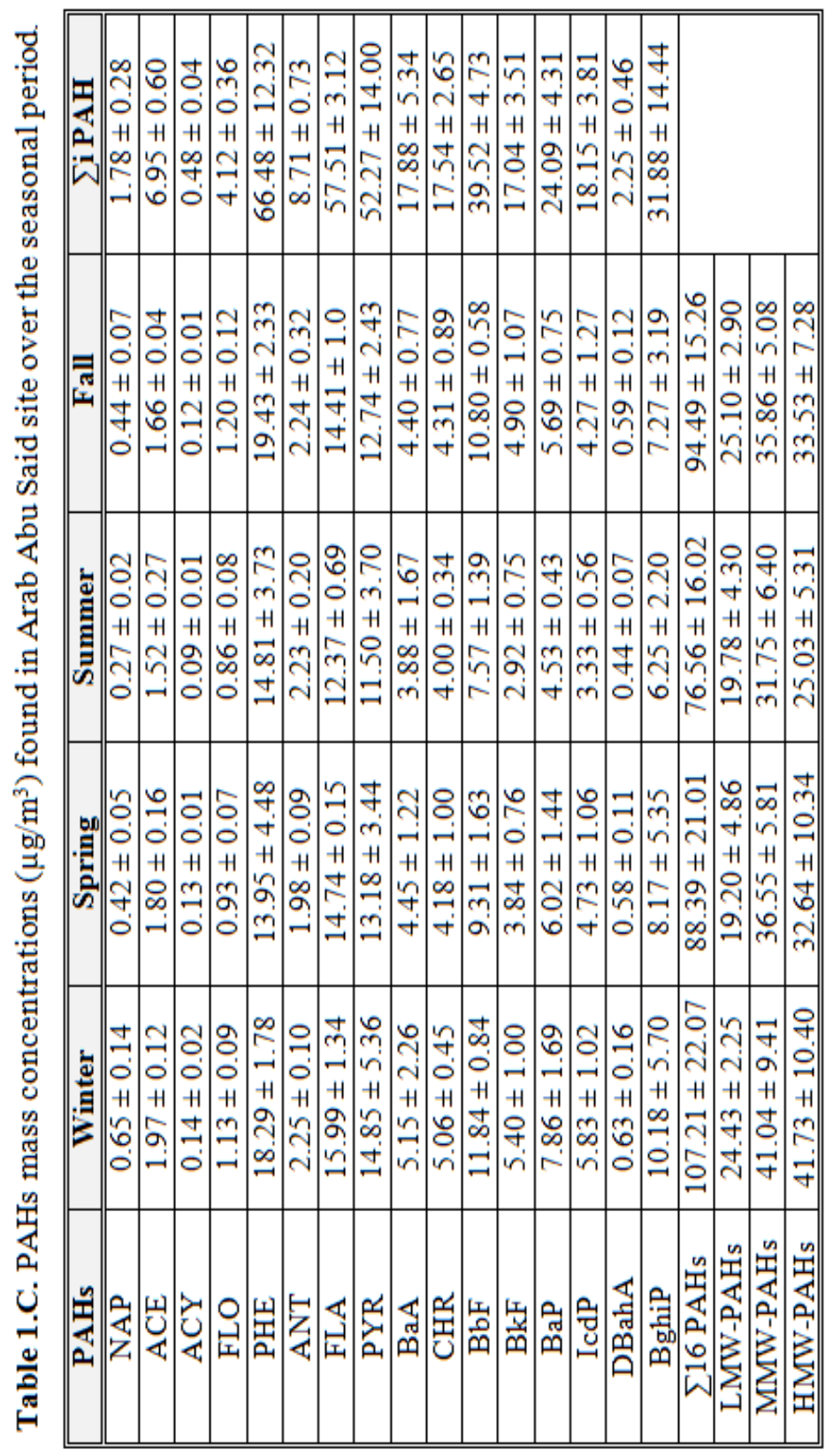




\begin{tabular}{|c|c|c|c|c|c|c|c|c|c|c|c|c|c|c|c|c|c|c|c|c|}
\hline 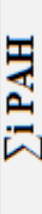 & 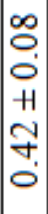 & $\mid \begin{array}{l}0 \\
-1 \\
0 \\
+1 \\
0 \\
0 \\
0 \\
-1\end{array}$ & 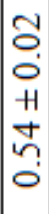 & $\begin{array}{l}5 \\
0 \\
0 \\
+1 \\
\vdots \\
0 \\
0 \\
0\end{array}$ & 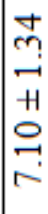 & 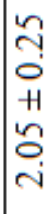 & $\begin{array}{l}a \\
-1 \\
+1 \\
6 \\
\sim \\
= \\
=\end{array}$ & $\begin{array}{l}\text { ग } \\
+ \\
+1 \\
0 \\
y \\
\text { J }\end{array}$ & $\begin{array}{l}0 \\
\text { m } \\
-1 \\
+ \\
7 \\
7\end{array}$ & $\begin{array}{l}m \\
\sigma \\
0 \\
+ \\
0 \\
\infty \\
m\end{array}$ & $\begin{array}{l}0 \\
+ \\
+1 \\
0 \\
0 \\
\sigma\end{array}$ & 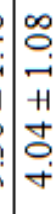 & $\begin{array}{l}n \\
m \\
-1 \\
+ \\
0 \\
n \\
n\end{array}$ & $\begin{array}{l}\text { 을 } \\
\text { - } \\
\text { H } \\
\text { 금 } \\
\text { v }\end{array}$ & 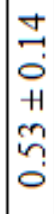 & 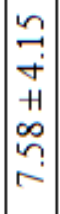 & & & & \\
\hline$\underset{\text { 幽 }}{=}$ & \begin{tabular}{l}
$\mathcal{N}$ \\
0 \\
0 \\
+1 \\
+ \\
0 \\
\hdashline \\
0
\end{tabular} & $\begin{array}{c}m \\
0 \\
0 \\
0 \\
H \\
0 \\
0 \\
0 \\
0\end{array}$ & \begin{tabular}{l}
-1 \\
0 \\
0 \\
+1 \\
$\sim$ \\
$\sim$ \\
\hdashline \\
0
\end{tabular} & 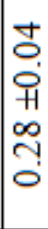 & 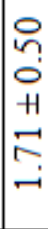 & 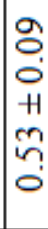 & 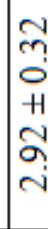 & $\begin{array}{l}n \\
0 \\
0 \\
+1 \\
- \\
0 \\
m\end{array}$ & $\begin{array}{l}0 \\
0 \\
+ \\
0 \\
0\end{array}$ & $\begin{array}{l}n \\
- \\
0 \\
+1 \\
\infty \\
\infty \\
0\end{array}$ & $\begin{array}{l}9 \\
2 \\
0 \\
+1 \\
+ \\
2 \\
2\end{array}$ & $\begin{array}{l}N \\
n \\
0 \\
+1 \\
0 \\
- \\
-1\end{array}$ & $\begin{array}{l}n \\
r \\
0 \\
+1 \\
+ \\
n \\
-\end{array}$ & $\begin{array}{l}0 \\
0 \\
0 \\
0 \\
+1 \\
-\overrightarrow{0} \\
-1\end{array}$ & 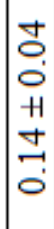 & $\begin{array}{c}n \\
\infty \\
0 \\
+ \\
+1 \\
+ \\
\Sigma \\
-\end{array}$ & $\mid \begin{array}{c}\mathcal{N} \\
\sim \\
+ \\
+1 \\
\sim \\
\infty \\
\infty \\
-1\end{array}$ & $\begin{array}{l}0 \\
0 \\
0 \\
+ \\
+1 \\
m \\
\text { m } \\
\text { m }\end{array}$ & $\begin{array}{c}N \\
J \\
- \\
H \\
\dot{J} \\
\infty \\
\sim\end{array}$ & $\begin{array}{l}\text { ב } \\
\text { N } \\
+ \\
+ \\
\text { J } \\
\sim\end{array}$ \\
\hline 离 & $\begin{array}{l}- \\
0 \\
0 \\
0 \\
+1 \\
0 \\
0 \\
0 \\
0\end{array}$ & $\begin{array}{l}n \\
0 \\
0 \\
+ \\
+1 \\
0 \\
0 \\
0 \\
0\end{array}$ & $\begin{array}{l}-1 \\
0 \\
0 \\
+1 \\
+ \\
0 \\
0 \\
0\end{array}$ & $\begin{array}{l}\text { m } \\
0 \\
0 \\
+ \\
+ \\
0 \\
0 \\
0 \\
0\end{array}$ & 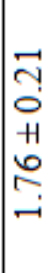 & $\begin{array}{l}\infty \\
0 \\
0 \\
+ \\
+1 \\
n \\
n \\
0 \\
0\end{array}$ & $\begin{array}{l}+ \\
\sim \\
0 \\
+1 \\
n \\
\sim \\
\sim\end{array}$ & $\begin{array}{l}\mathcal{J} \\
\mathcal{H} \\
+ \\
\sim \\
\sim \\
\sim\end{array}$ & $\begin{array}{l}\tilde{y} \\
0 \\
+ \\
\mathrm{m} \\
0 \\
0\end{array}$ & $\begin{array}{l}n \\
0 \\
0 \\
+1 \\
n \\
\infty \\
0 \\
0\end{array}$ & $\mid \begin{array}{l}\infty \\
2 \\
0 \\
+1 \\
2 \\
-\end{array}$ & \begin{tabular}{c} 
I \\
\hdashline \\
0 \\
+1 \\
$g$ \\
0 \\
0
\end{tabular} & $\begin{array}{l}2 \\
0 \\
+1 \\
0 \\
0\end{array}$ & $\begin{array}{c}0 \\
\stackrel{2}{0} \\
0 \\
+ \\
\infty \\
\infty \\
0 \\
0\end{array}$ & 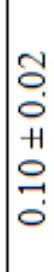 & $\begin{array}{c}n \\
n \\
0 \\
+1 \\
\infty \\
\infty \\
+ \\
-\end{array}$ & 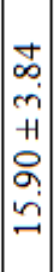 & 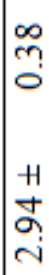 & $\begin{array}{c}-1 \\
\sim \\
\sim \\
H \\
-1 \\
0 \\
-\end{array}$ & 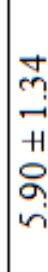 \\
\hline 尝 & \begin{tabular}{l}
$\mathcal{N}$ \\
0 \\
0 \\
+1 \\
0 \\
0 \\
\hdashline \\
0
\end{tabular} & 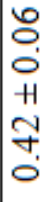 & $\begin{array}{l}-1 \\
0 \\
0 \\
+1 \\
1 \\
0 \\
0 \\
0\end{array}$ & $\begin{array}{l}\mathcal{N} \\
0 \\
0 \\
H \\
\text { H } \\
\text { N } \\
0\end{array}$ & $\begin{array}{l}m \\
m \\
0 \\
+1 \\
n \\
0 \\
-1\end{array}$ & 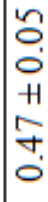 & $\begin{array}{l}0 \\
\text { rn } \\
0 \\
+ \\
0 \\
\text { o } \\
\text { ci }\end{array}$ & $\begin{array}{c}0 \\
\sim \\
0 \\
+1 \\
m \\
m \\
m\end{array}$ & $\begin{array}{l}2 \\
0 \\
+1 \\
-\end{array}$ & $\begin{array}{l} \pm \\
\text { J } \\
0 \\
+ \\
\infty \\
0 \\
0\end{array}$ & $\begin{array}{l}n \\
0 \\
+1 \\
0 \\
n\end{array}$ & 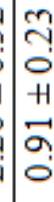 & $\begin{array}{l}+ \\
m \\
0 \\
+1 \\
m \\
y \\
-\end{array}$ & 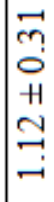 & $\begin{array}{c}m \\
0 \\
0 \\
+1 \\
+ \\
+ \\
\stackrel{0}{0}\end{array}$ & 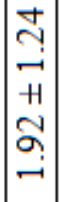 & $\mid \begin{array}{c}m \\
- \\
\sim \\
+1 \\
-1 \\
\infty \\
\infty \\
-\infty \\
-1\end{array}$ & 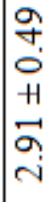 & $\begin{array}{c}\infty \\
\infty \\
- \\
-1 \\
0 \\
\sigma \\
- \\
\infty\end{array}$ & $\begin{array}{l}0 \\
N \\
N \\
+ \\
- \\
-\end{array}$ \\
\hline 离 & $\mid$\begin{tabular}{c} 
\pm \\
0 \\
0 \\
+1 \\
+1 \\
$n$ \\
\hdashline \\
\hdashline
\end{tabular} & $\begin{array}{l}-1 \\
0 \\
0 \\
+ \\
+1 \\
0 \\
0 \\
0 \\
0\end{array}$ & $\begin{array}{c}m \\
0 \\
0 \\
0 \\
H \\
+ \\
m \\
0\end{array}$ & 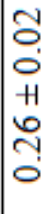 & 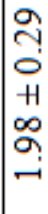 & $\begin{array}{c}m \\
0 \\
0 \\
+ \\
+ \\
m \\
n \\
0 \\
0\end{array}$ & $\begin{array}{l}0 \\
0 \\
0 \\
+1 \\
0 \\
\ddots \\
m \\
m\end{array}$ & $\begin{array}{l}0 \\
\text { f } \\
\stackrel{+}{+} \\
m \\
\text { m }\end{array}$ & $\begin{array}{l}2 \\
0 \\
+1 \\
0 \\
0 \\
0\end{array}$ & $\begin{array}{l}0 \\
- \\
0 \\
+1 \\
0 \\
= \\
-\end{array}$ & $\begin{array}{l}2 \\
0 \\
+1 \\
o \\
2 \\
n\end{array}$ & $\begin{array}{l}\sim \\
\sim \\
0 \\
+1 \\
\infty \\
\sim \\
-1\end{array}$ & $\begin{array}{l}0 \\
\curvearrowleft \\
0 \\
+1 \\
0 \\
\infty \\
-\end{array}$ & $\begin{array}{l}N \\
n \\
0 \\
+ \\
\infty \\
\infty \\
n \\
-\end{array}$ & 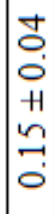 & $\begin{array}{c}-\tilde{n} \\
- \\
+1 \\
\sim \\
y \\
\sim\end{array}$ & 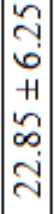 & $\begin{array}{l}a \\
m \\
0 \\
H \\
m \\
m \\
m\end{array}$ & $\begin{array}{l}-\overrightarrow{ } \\
\infty \\
\tilde{y} \\
+ \\
\sim \\
\tilde{\sigma} \\
\sigma\end{array}$ & $\begin{array}{l}\text { n } \\
\text { m } \\
+1 \\
\circ \\
0 \\
\text { a }\end{array}$ \\
\hline 党 & 吾 & 团 & 0 & $\begin{array}{l}0 \\
\\
1\end{array}$ & 畄 & 占 & 寽 & 佂 & ఝ & 岳 & $\frac{1}{n}$ & $\frac{5}{m}$ & 空 & 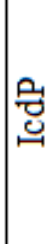 & 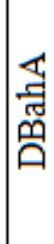 & 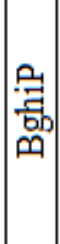 & $\mid \begin{array}{l}0 \\
\text { 焉 } \\
0 \\
0 \\
0 \\
\vdots\end{array}$ & 夏 & 焉 & 焉 \\
\hline
\end{tabular}


Indubitably, the environmental locations of the sampling sites are considered as an important contributor to the concentrations of atmospheric PAHs. Because the sources of PAHs are almost related to combustion, the specific local sources may lead to the differences of PAH concentrations for different sites in a city or area under study. Therefore, the comparison studies of atmospheric PAHs in different functional zones are necessary for establishing effective controlling measures in an urban area. Furthermore, owing to difference of population, traffic density and industry distribution, the PAH contribution from anthropogenic inputs varied in different function zones (Lodovici et al., 2003; Kong et al., 2010; Kim et al., 2013).

Accordingly, the sampling strategy in this study was applied to different functional zones (i.e. CK, TIMS, AAS and RA) in order to determine the total PAHs concentrations in the south of El Tabbin city with $25 \mathrm{~km}^{2}$.

\section{CONCLUSION}

In this study, 16 PAHs in particulate and gaseous phases (LMW and MMW -PAHS represents the gas phase) (HMW -PAHS represent the solid phase) were identified and quantified in 48 atmospheric air samples from 4 sampling sites in four seasons from January to November 2014 at the south of El Tabbin city in order to determine the concentration levels, seasonal variations and their potential sources. The results showed the mass concentration of PAHs with the highest concentrations at the industrial areas (CK, TIMS and AAS) following by residential area (RA). It was found that PAHs concentrations were high in winter and autumn at the four sampling sites where it take the order of winter $>$ autumn $>$ spring $>$ summer. This 38 
behavior could be attributed to the meteorological factors such as regional climatic conditions, lower atmospheric mixing height, decreased sunlight intensity as well as frequent temperature inversion that intensify the PAH pollution in winter. Atmospheric outflow was estimated based on the concentration of PAHs and wind velocity where the elevated transport fluxes were found during the spring and winter seasons and southeastward transport is dominated.

Among the 16 PAHs, FLA, PYR, CHR, BbF, BkF, BaA, BaP, IcdP, BghiP (represent combustion derived PAHs) were most abundant, which reflects the influence of combustion processes (either coal or oil) and vehicle emission. Predominantly coal combustion, vehicle emission (including diesel and gasoline fuel exhaust) and industrial processes are the primary sources for atmospheric PAHs in this heavy-industrialized city. BaP concentration in the study area is extremely high where the average $\mathrm{BaP}$ concentration over seasonal sampling period for the study area, reflecting a serious hidden danger to health.

\section{REFERENCES}

Arditsoglou, A.; Petaloti, C.; Terzi, E.; Sofoniou, M. and Samara, C. (2004): Size distribution of trace elements and polycyclic aromatic hydrocarbons in fly ashes generated in Greek lignite-fired power plants. Sci. Total Environ. 323: 153-167.

Bourotte, C., Forti, M.C., Taniguchi, S., Caruso, M. and Lotufo, P.A., (2005): A wintertime study of PAHs in fine and coarse aerosols in Sao Paulo City, Brazil. Atmos. Environ. 39: 3799-3811. 
Chen, S.; Su, B.; Chang, J.E.; Lee, W.J.; Huang, K.L.; Hsieh, L.T.; Huang, J.C.; Lin, W.J. and Lin, C.C. (2007): Emissions of polycyclic aromatic hydrocarbons (PAHs) from the pyrolysis of scrap tires. Atmos. Environ. 41: 1209-1220.

Chen, S.J., Hsieh, L.T. and Chiu, S.C. (2003) :Emission of polycyclic aromatic hydrocarbons from animal carcass incinerators. Sci. Total Environ. 313: 61-76.

Gardner, B., Hewitt, C.N. and Jones, K.C., (1995): PAHs in air adjacent to two inland water bodies. Environ. Sci. Technol. 29, 2405-2413.

Johansson, I. and Bavel, B.V. (2003): polycyclic aromatic hydrocarbons in weathered bottom ash from incineration of municipal solid waste. Chemosphere 53: 123-128

Khalili, N.R.; Scheff, P.A. and Holsen, T.M. (1995): PAH source fingerprints for coke ovens, diesel and gasoline engines, highway tunnels, and wood combustion emissions. Atmos. Environ. 29: 533-542.

Kim, K. H.; Jahan, S. A.; Kabir, E. and Brown, R. J. (2013): A review of airborne polycyclic aromatic hydrocarbons (PAHs) and their human health effects. Environ. Int. 60: 71-80

Manoli, E.; Kouras, A. and Samara, C. (2004): Profile analysis of ambient and source emitted particle-bound polycyclic aromatic hydrocarbons from three sites in northern Greece. Chemosphere 56: 867-878.

Park, S.S.; Kim, Y.J. and Kang, C.H. (2002): Atmospheric polycyclic aromatic hydrocarbons in Seoul, Korea. Atmos. Environ. 36: 2917-2924.

Terzi, E. andSamara, C., (2004): Gas/particle partitioning of polycyclic aromatic hydrocarbons in urban, adjacent coastal, and continental background sites of western Greece. Environ. Sci. Technol. 38, 4973-4978.

Ravindra, K.; Bencs, L.; Wauters, E.; de Hoog, J.; Deutsch, F.; Roekens, E.; Bleux, N.; Bergmans, P. and Van Grieken, R. (2006):Seasonal and site specific variation in vapor and aerosol phase PAHs over 
Flanders (Belgium) and their relation with anthropogenic activities. Atmos. Environ. 40: 771-785.

US-EPA Method TO-13A (Compendium Method for determination of PAHs in ambient air)

Lodovici C.; Fortic, M.C.; Taniguchi, S.; Bicego, M.C. and Lotufo, P.A. (2005): A wintertime study of PAHs in fine and coarse aerosols in Sao Paulo city, Brazil. Atmos. Environ. 39: 3799-3811.

Kong, S.F.; Ding, X.; Bai, Z.P.; Han, B.; Chen, L.; Shi, J.W. and Li, Z.Y. (2010): A seasonal study of polycyclic aromatic hydrocarbons (PAHs) in fine and coarse atmospheric particulate matter in five typical cities of Liaoning Province, China. J. Hazard. Mater. 183: $70-80$.

USEPA (U.S. Environmental Protection Agency) (1999): Integrated Risk Information System (IRIS) on Polycyclic Organic Matter. National Center for Environmental Assessment, Office of Research and Development, Washington, DC.

USEPA (U.S. Environmental Protection Agency) (2000): Deposition of air pollutants to the great waters: third report to congress. Office of Air Quality Planning and Standards. EPA-453/R-00-0005.

USEPA (U.S. Environmental Protection Agency) (2008): Polycyclic aromatic hydrocarbons (PAHs) - EPA fact sheet. United States Office of Solid Waste, Environmental Protection Agency, 2046Washington, DC: National Center for Environmental Assessment, Office of Research and Development.

Yang, H.H.; Lee, W.J.; Chen, S.J. and Lai, S.O. (1998): PAH emission from various industrial stacks. J. Haz. Mat. 60: 159-174.

You, X.F. (2008) :polycyclic aromatic hydrocarbon (PAH) emission from cofiring municipal solid waste (MSW) and coal in a fluidized bed incinerator. Waste Manag. 28: 1543-1551. 


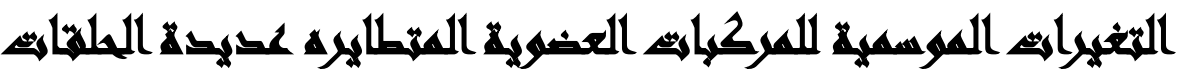

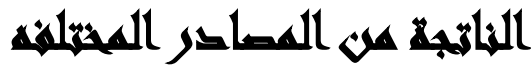

$[r]$

$$
\begin{aligned}
& \text { محمد إبراهيم حويحي(')- أثرف عبد الحميد زهران(؟)- مصطفى حسن رجب(') } \\
& \text { محمود محمد نور الدين }
\end{aligned}
$$

(1) معهد الدراسات والبحوث البيئية، جامعة عين شمس ب) معهد الدراسات والبحوث البيئية، جامعة

\section{المستخلم:}

من المهم فهم التخيرات الموسمية المركبات العضوية عديدة الحلقات فى المناطق الحضرية

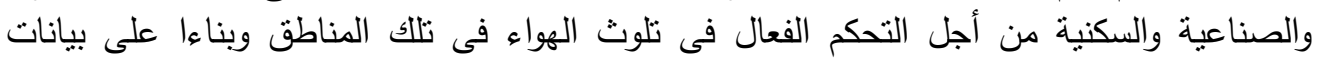

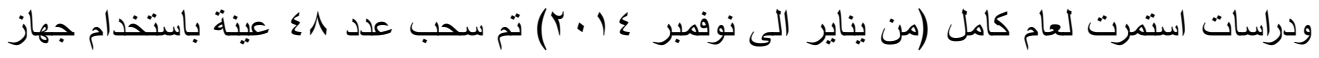

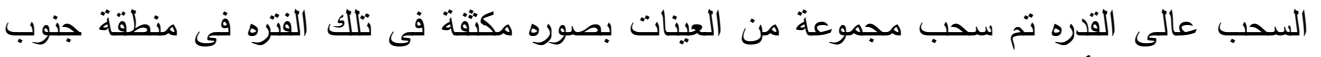

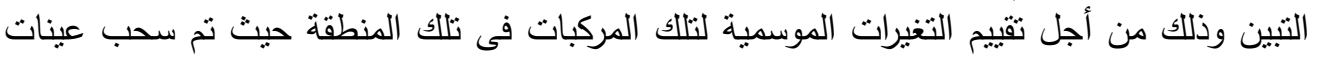

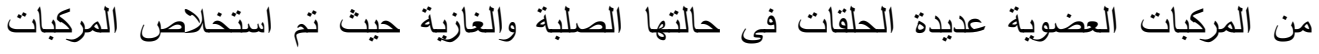

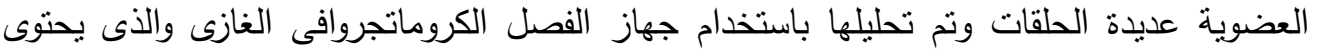

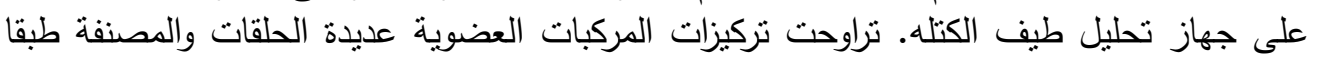

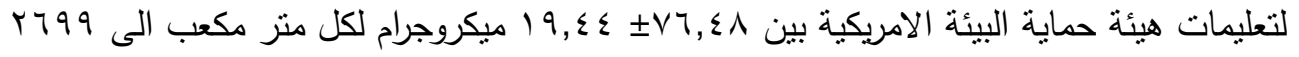

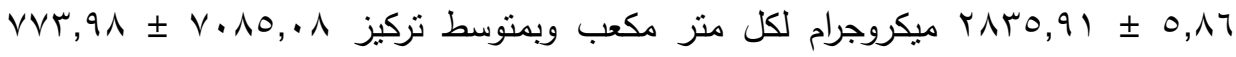
ميكروجرام لكل متر مكعب. اختلفت نركيزات المركبات العضوية عدية عديدة الحلقات باختلاف موقع القباسات.

تم تحديد التغيرات الموسمية للمركبات العضوية عديدة الحلقات حيث جاءت التركيزات عالية فى التى

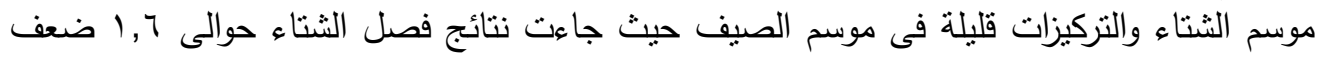
نتائج فصل الصيف والذى من الممكن تقسيره باستخدام العوامل المناخية. 